\title{
Effectiveness of Cardiovascular Specific Psychotherapy on Heart Disease Patients' Quality of Life
}

\begin{abstract}
Background and objective: Cardiovascular diseases (CVDs) is one of the causes of death worldwide. CVDs covers a wide array of disorders, including diseases of the cardiac muscle and of the vascular system supplying the heart, brain, and other vital organs. The aim of the paper was to study the effectiveness of cardiovascular specific psychotherapy on the patients' quality of life.

Materials and methods: In this quasi-experimental study 30 patients with heart disease from Rasol-e-Akram hospital in the city of Rasht were selected by accessible sampling method, and randomly placed in two experimental and control groups. Experiment and control groups completed the WHOQOL questionnaire before and after the intervention. The intervention was implemented in 25 sessions (each 150 minutes) for patients in the test group. Data was analyzed by MANCOVA test using SPSS19.

Results: The mean scores of quality of life and its subscales, before and after the intervention, statistically had significant difference $(p<0.05)$. Therefore, it seems that cardiovascular specific psychotherapy was effective on the promotion of patients' quality of life.

Conclusion: This kind of therapy is effective in improving life quality of cardiovascular patients. Therefore, it is recommended as an effective therapy to improve mental health.

Paper Type: Research Article.

Keywords: Cardiovascular disease (CVD), Psychotherapy, Psychocardiology, Quality of life, Rasht.
\end{abstract}

Citation: Soltani-shal R, Aghamohammadian-Sharbaf HR, Abdekhodaei MS, Tayyebi M. Effectiveness of cardiovascular specific psychotherapy on heart disease patients' quality of life. Iran J Health Educ Health Promot. Autumn 2016;4(3): 244-254.

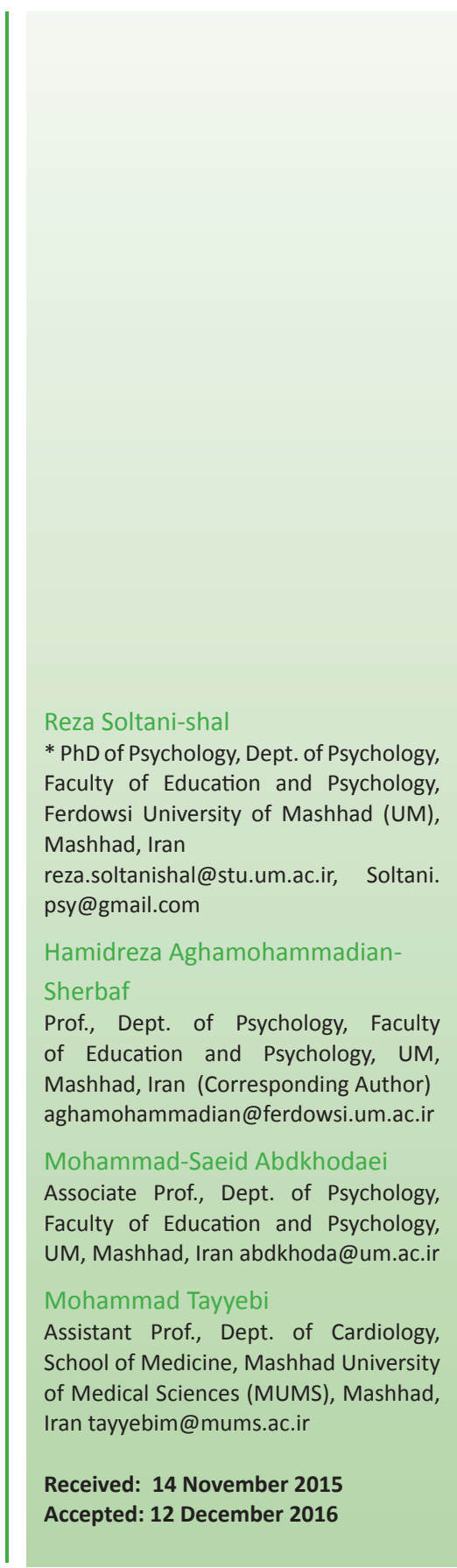




\section{اثربخشى الكّوى رواندرمانى ويزٔه بيماران قلبى بر كيفيت زندكى آنها}

رضا سلطانى شال، دكترى روانشناسى، كروه روانشناسى، دانشكده علوم تربيتى و روانشناسى، دانشكاء فردوسى مشهد، مشهد، ايران reza.soltanishal@stu.um.ac.ir, Soltani. psy@gmail.com

$$
\text { حميدرضا آقامحمديان شعرباف }
$$

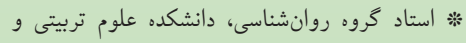
روانشناسى، دانشكاء فردوسى مشهد، مشهد، ايران

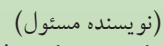
aghamohammadian@ferdowsi.um.ac.ir

محمد سعيد عبدخدايى

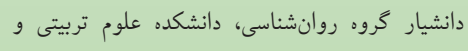

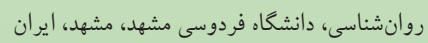
abdkhoda@um.ac.ir

$$
\text { محمد طيبى }
$$

استاديار كروه قلب و عروق، دانشكده يِ شكى، دانشكاه

علوم يز شكى مشهد، مشهد، ايران tayyebim@mums.ac.ir

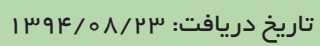

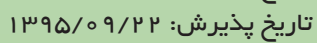

\section{جكيده}

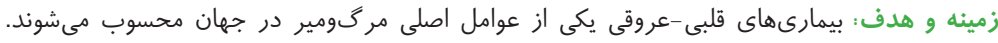

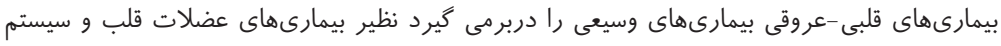

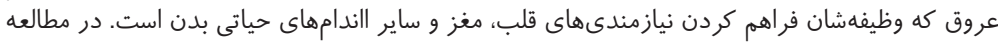

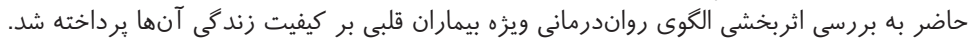

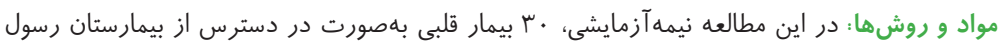

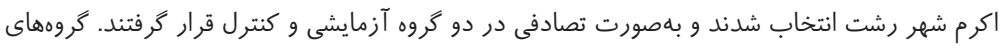

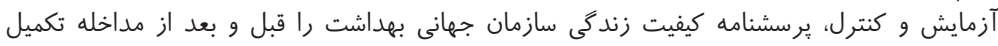

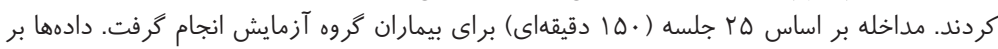

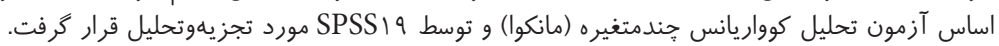

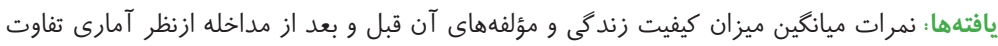

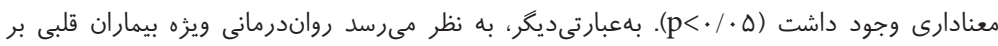

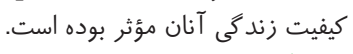

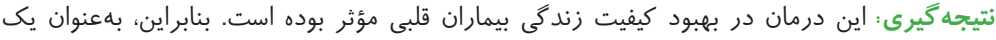

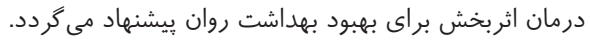

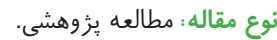
كليدوازه : بيمارى قلبى و عروقى، رواندرمانى، روانقلبشناسى، بيماران قلبى، كيفيت زندگى، رشت.

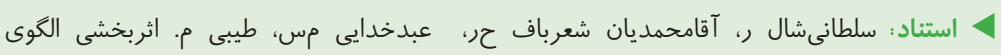

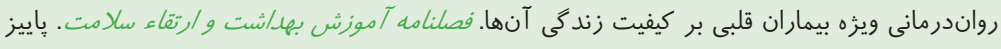

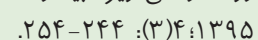


درحال توسعه به شمار مىرود (9). در همين راستا، بُزوهشگران

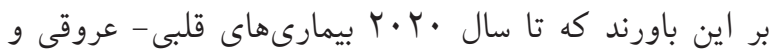

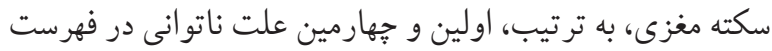

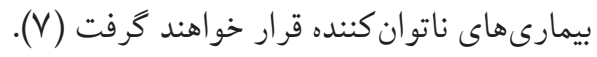

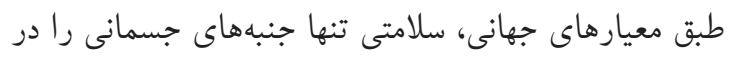

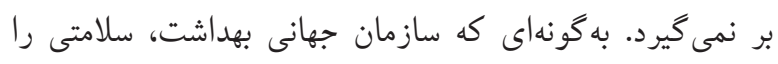

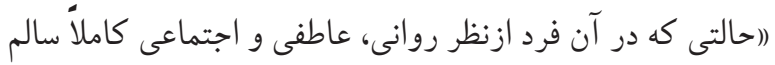

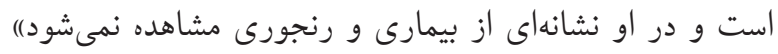

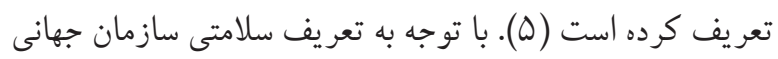

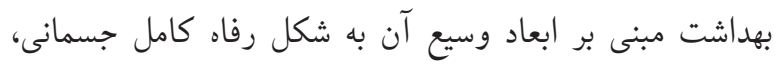

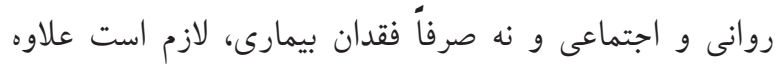

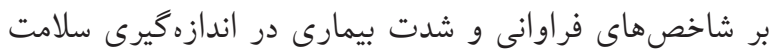
و ارزيابى مداخلات بهداشتى به ساير ارزشهاى انس انسانى مانند

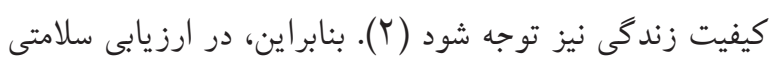

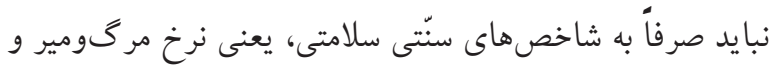

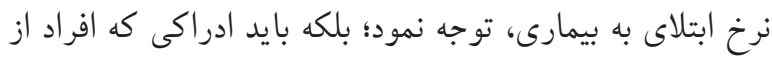

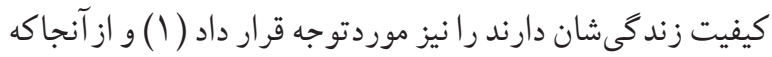
كيفيت زندگى ابعاد متعددى نظير اجتماعى، هيجانى، جسمانى،

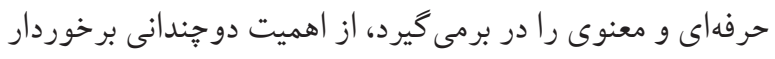

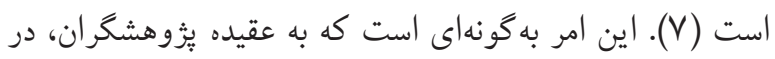

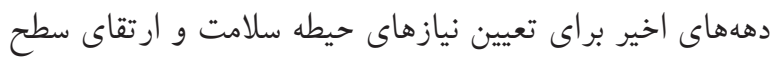

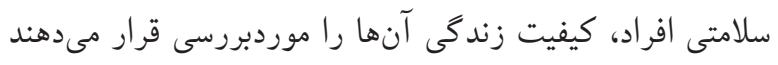

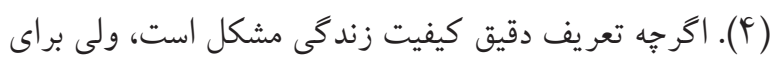
بيشتر مردم يك مفهوم گسترده دارد. اين مفهوم شامل رضايت از ردئ زندكى در همه زمينهها مانند وضعيت سلامتى، اشتغال، مسكن مردم

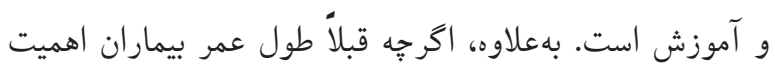
بسيارى داشت، ولى امروزه كيفيت زندكى بيماران نيز موردتوجه

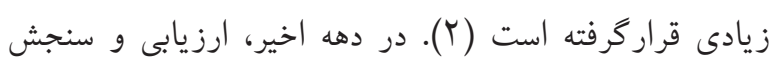
كيفيت زندگى در ميان بسيارى از متخصصان در حيطههاى

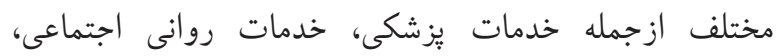

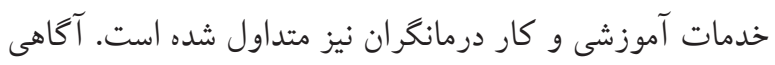
با صنعتىشدن جوامع، علل مهم مرگ و ازكارافتادگىهاى ناشى

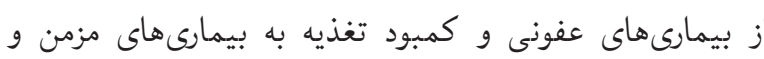

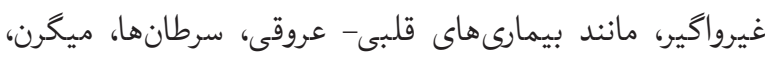
يرفشارىخون، دردهاى كليوى و ديابت، تغيير يافت. اين تحول

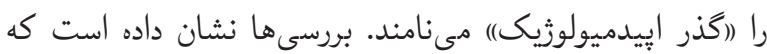

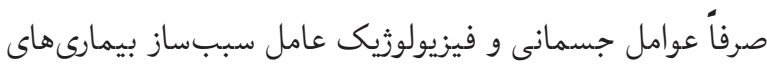
مزمن و غيرواكير نيستند؛ بلكه متغيرهاى روانشناختى نيز بهصورت مستقيم و غيرمستقيم زمينه مساعدى براى ابتلاى افراد

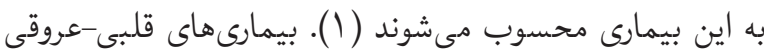

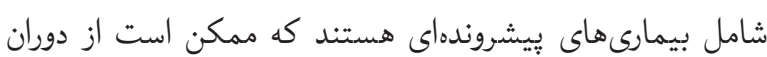

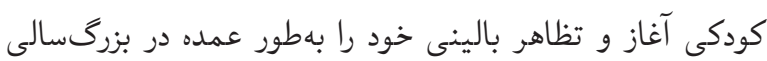

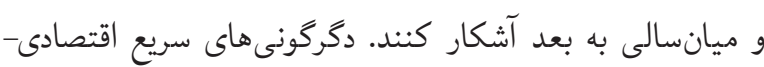
اجتماعى دهههاى اخير در بسيارى از كشورهاى شرق مديترانه

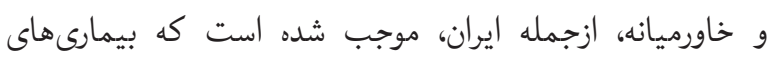
قلبى-عروقى يك مشكل عمده بهداشتى و اجتماعى به شمار

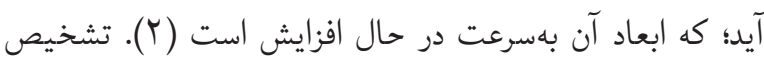
بيمارىهاى قلبى-عروقى علاوه بر مطرح نمودن مشكلات جسمى، باعث اختلالات قابل توجه در وضعيت روانى بيماران مىشود (ץ). ازجمله اين اختلالات مىتوان به اضطراب، افسردگى و اطمينان

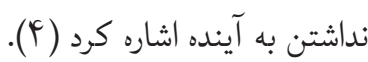

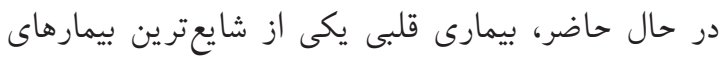
مزمن و مهمترين علت بسترى افراد در بيمارستان است (ه). امروزه، بيمارىهاى قلبى يكى از عوامل اصلى مر گرومير در جهان

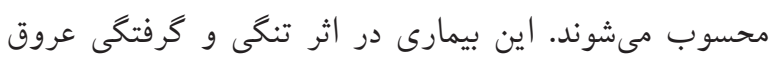

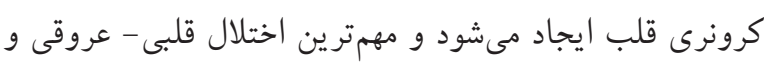
يك مشكل بهداشتى در كشورهاى درحالتوسعه و توسعهيافته است. در شــروع قرن بيستم اختلال قلبى - عروقى كمتر از

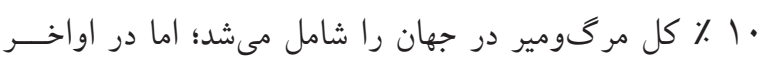

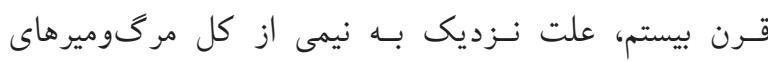

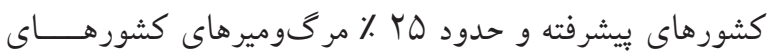


مو اد و روشها در اين طرح نيمهآزمايشى، گروه آزمايش مورد مداخله قرار كرفت

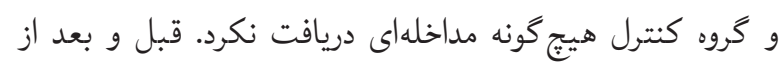

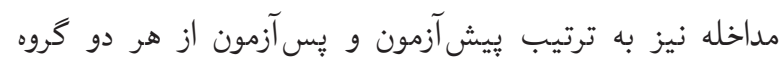

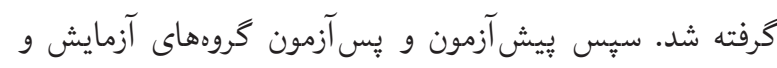

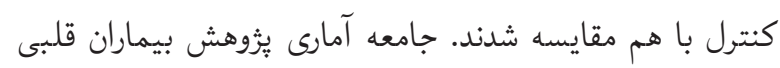

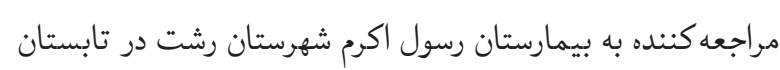

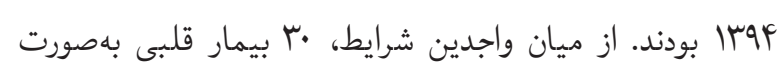

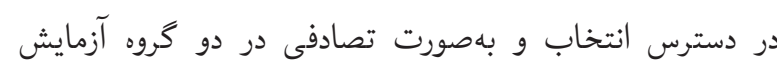
و كنترل جايكزين شدند. شركت در يُّوهش براى تمامى افراد

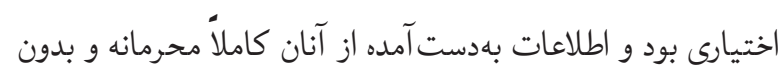
ذكر مشخصات هويتى جمع آورى شد. بيماران داراى شرايط حاد

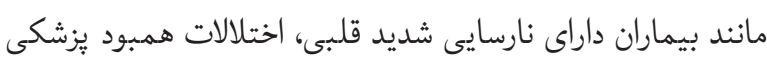

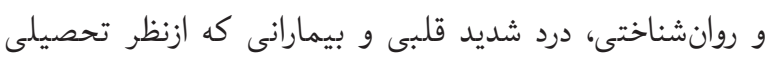

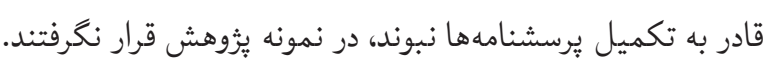
براى تجزيهوتحليل داده توصيفى از ميانكين و انحراف استاندارد

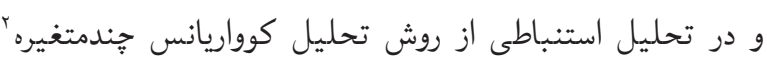

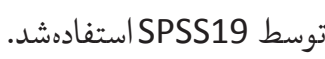

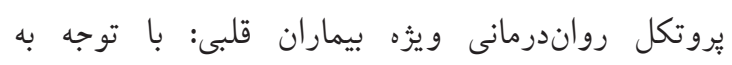

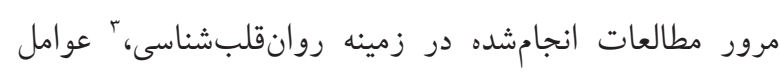
روانشناختى سببساز بيمارىهاى قلبى غيروراثتى در ايران عبارتاند از: اختلالات خلقى، اضطراب، طرحواره شناختى و ونئي

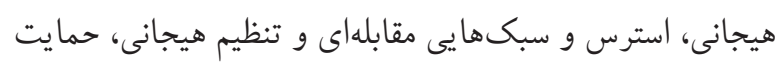

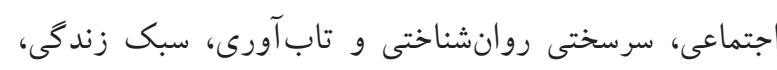

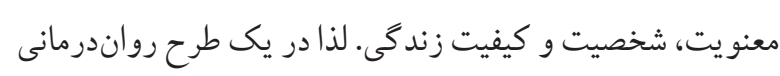
و يزه بيماران قلبى مىتوان اين متغيرهاى روانشناختى سببس دساز

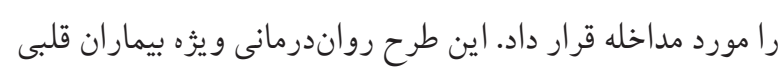

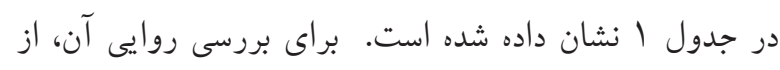

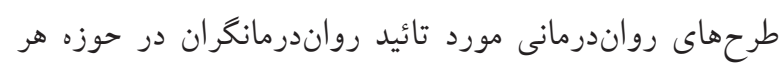
يك از عوامل روانشناختى سببساز بهره كرفته شد. ازنظر موند 2. MANCOVA

3. psychocardiology
از اهميت ارزيابى و سنجش كيفيت زندگى افراد در زمينها و

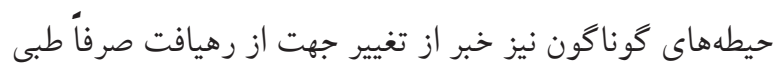

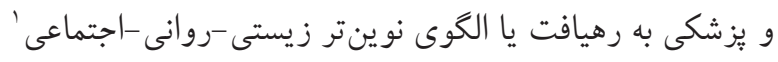

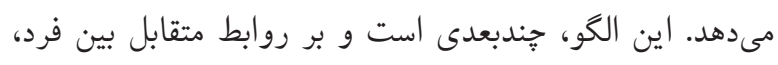

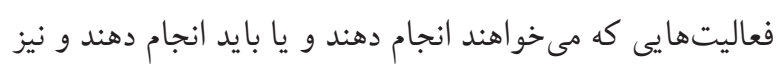

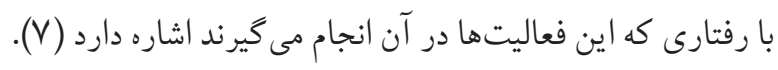

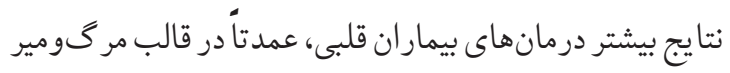

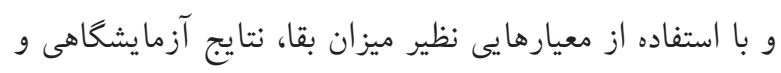

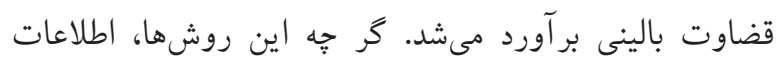

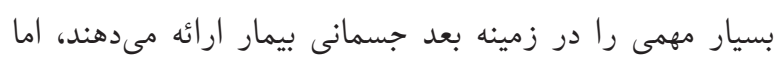

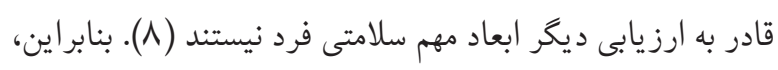

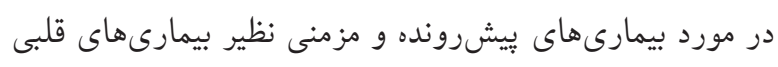

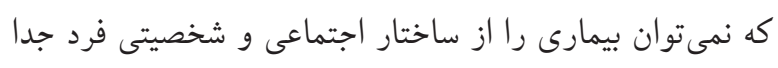

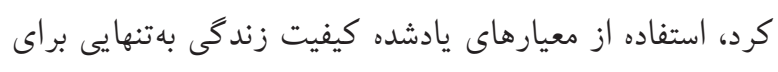

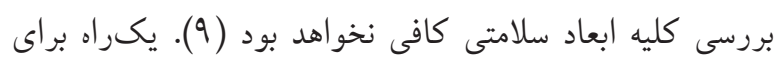

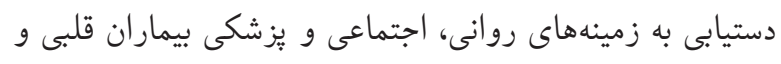
درمان همهجانبه آنها، درنظر كرفتن درمان همه جانبهاى است تاني

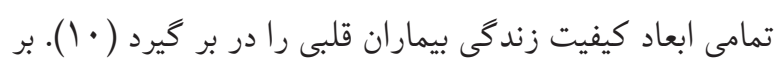

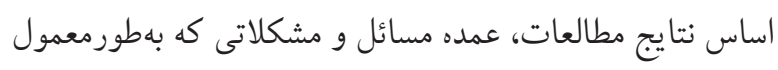
كيفيت زندكى مبتلايان به بيمارى قلبى را تحت تأثير قرار مىدهد عبارتاند از: آثار روانى و عاطفى ناشى از ابتلا به بيمارى بـى بيماري

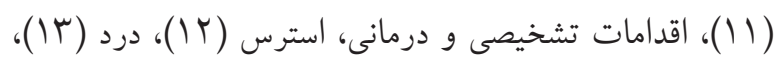

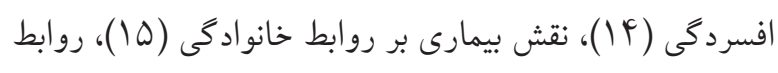

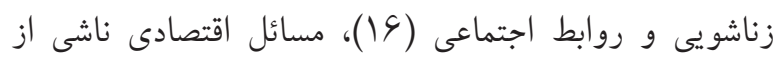

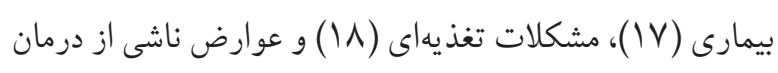
(19). بنابراين، تدوين درمان ويثه بيماران قلبى و انجام مداخله

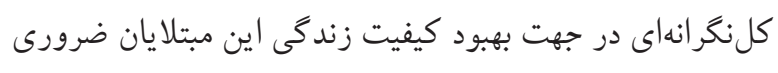
به نظر مىرسد. در همين راستا، مطالعه حاضر به اثربخشى درمان

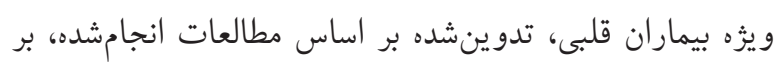

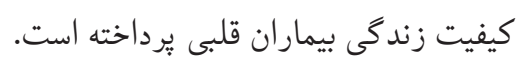

1. biopsychosocial model 
جدول ا. يروتكل رواندرمانى ويثه بيماران قلبى

\begin{tabular}{|c|c|}
\hline محتواى جلسات & جلسات \\
\hline 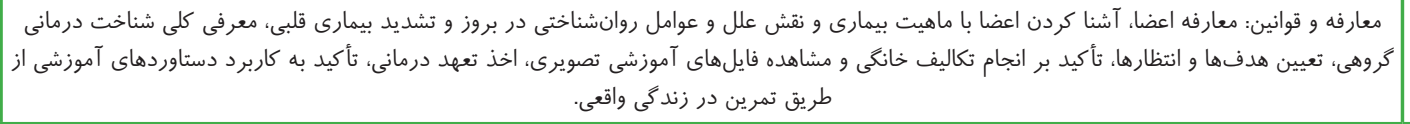 & اول و دوم \\
\hline 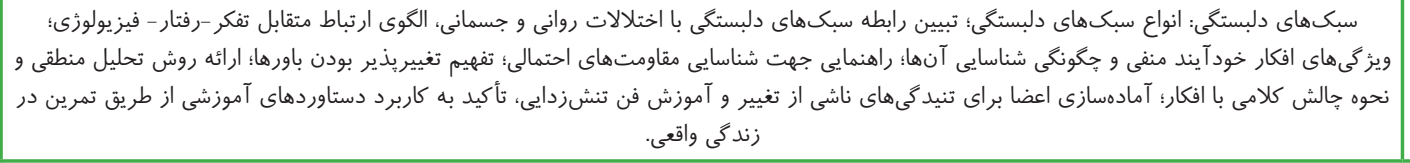 & سوم وجهارم \\
\hline 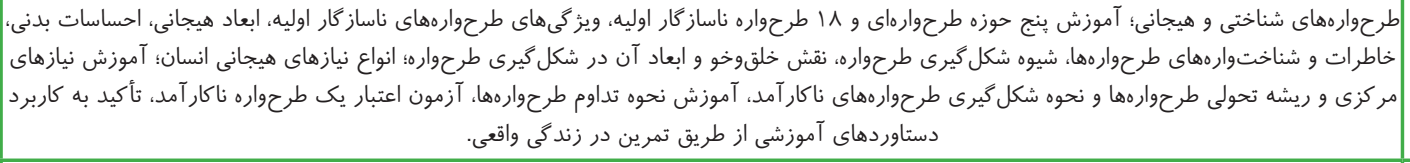 & يُجم و ششم \\
\hline 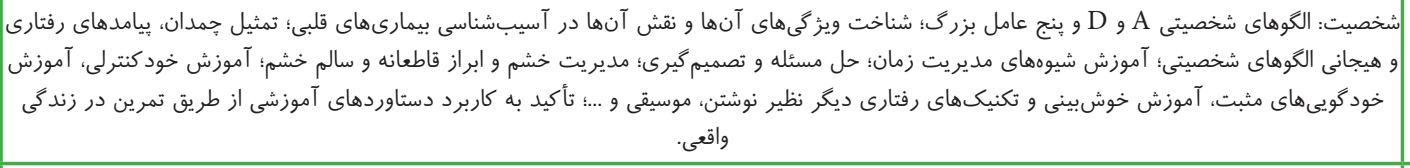 & هفتم و هشتم \\
\hline 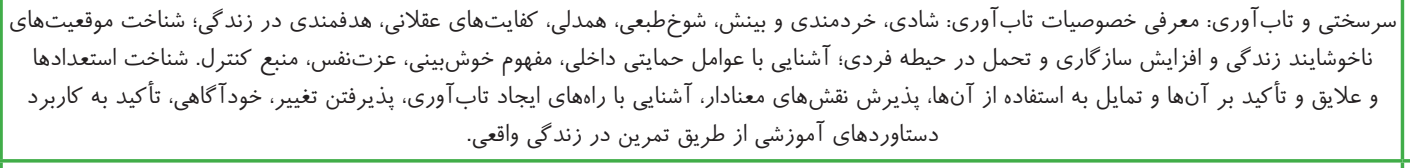 & نهم و دهم \\
\hline 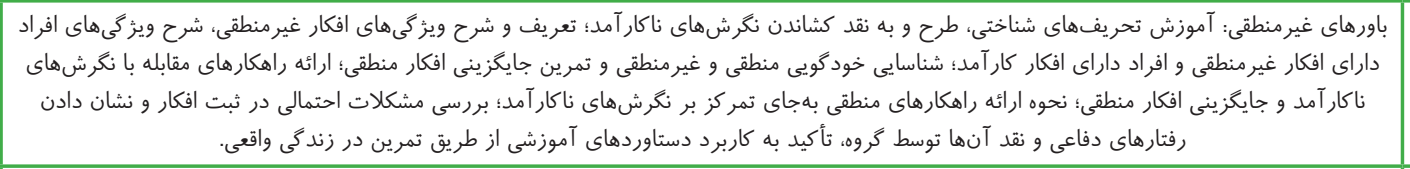 & دوازدهم \\
\hline 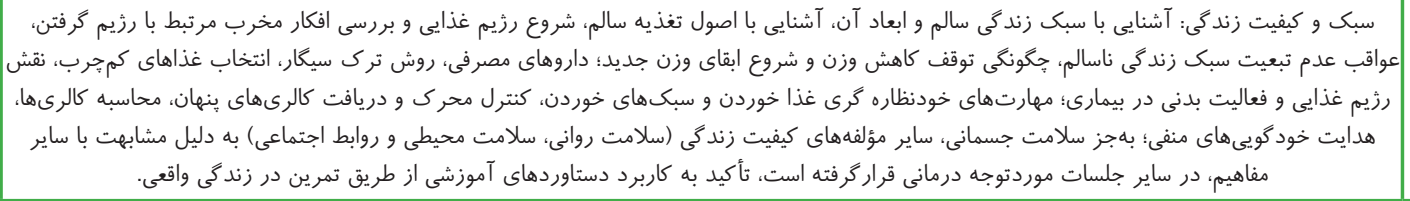 & 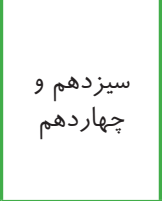 \\
\hline 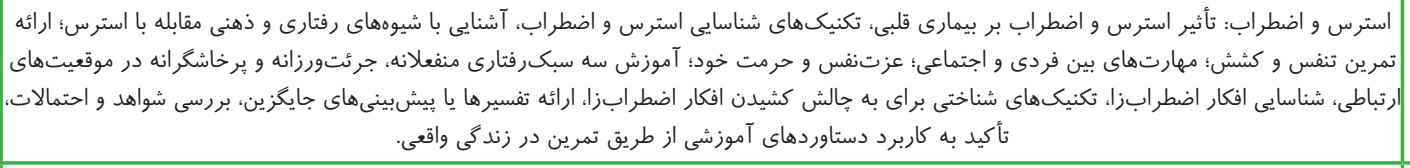 & شانز دهمم \\
\hline 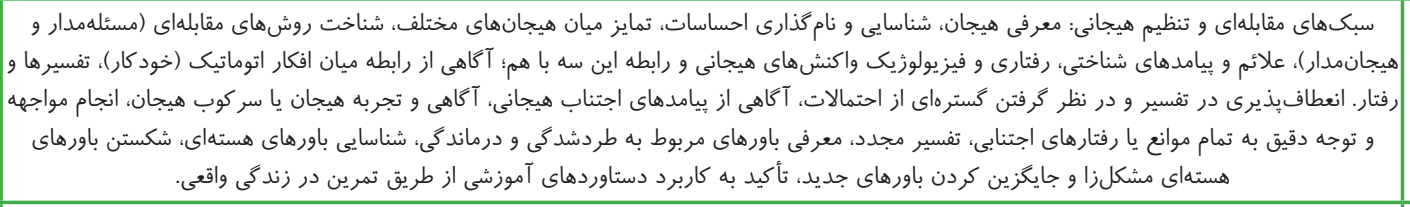 & ه هذدهم \\
\hline 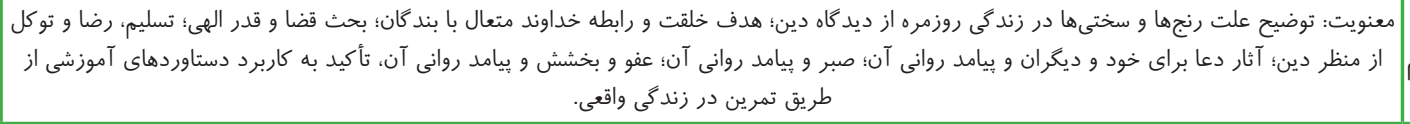 & نوزدهم و بيستم| \\
\hline 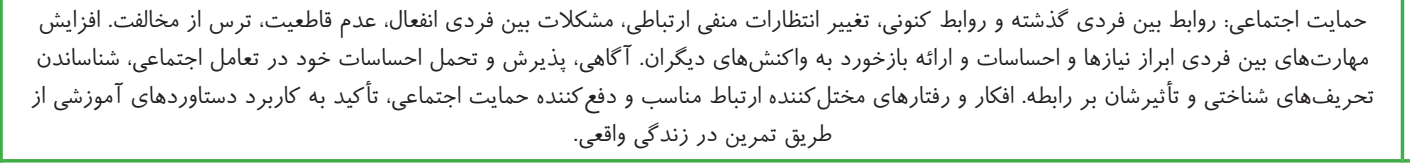 & 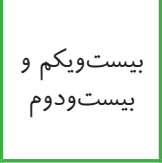 \\
\hline 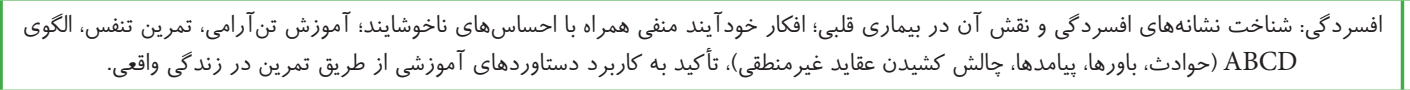 & بيستو بيسوسوم و \\
\hline جمع بندى و مرور، بازخورد از بيماران و اجراى يِ آزمون. & بيستوينجم \\
\hline
\end{tabular}


(Y. (†). اين مقياس در ايران هنجاريابى شده است و ضريب

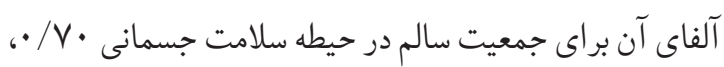

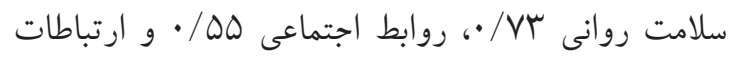

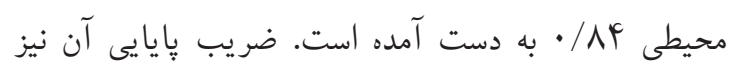

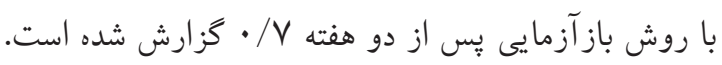

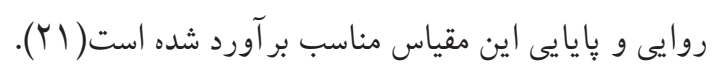

ياقتهاهـا

تمامى شركت كنندكان در مطالعه متأهل بودند. در گروه آزمايش

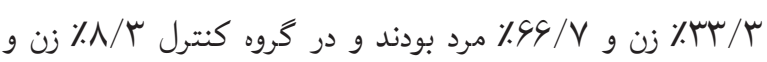

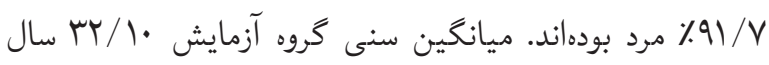
و كروه كنترل

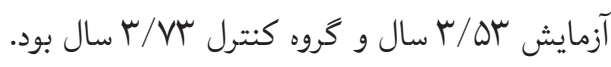

جدول r. آمارههاى توصيفى كيفيت زندگى در گروههاى كنترل و

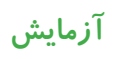

\begin{tabular}{|c|c|c|c|c|c|}
\hline \multicolumn{5}{|c|}{ كروه } & \multirow{3}{*}{ زبعاد كيفيت } \\
\hline \multicolumn{2}{|c|}{ كنترل } & \multicolumn{2}{|c|}{ آزمايش } & \multirow[b]{2}{*}{ زمان } & \\
\hline انحراف معيار & ميانكين & انحرافمعيار & ميانكين & & \\
\hline $1 / r F$ & $\Lambda / \cdot \Lambda$ & $r / F 1$ & N/A & ييش آزمون & \multirow{2}{*}{ جسمى } \\
\hline $1 / 10$ & ( & $1 / 9 V$ & $1 \cdot / S V$ & ״ֵس آزمون & \\
\hline $1 / 4$ & $1 \cdot / V \Delta$ & $r / F q$ & $N / S V$ & يِيش آزمون & \multirow{2}{*}{ روانى } \\
\hline $1 / 91$ & $11 / v \Delta$ & $1 / 1 V$ & $1 \pi / \Delta$ & ״ֶ آزمون & \\
\hline $1 / 8 \Lambda$ & $1 r / 0$ & $r / 10$ & $1 r / 0$ & يِش آزمون & \multirow{2}{*}{ اجتماعى } \\
\hline $1 / 01$ & $I r / F r$ & $1 / 0$ & س & پس آزمون & \\
\hline $1 / 19$ & $11 / 18$ & $1 / 94$ & $1 \cdot / 0 \Lambda$ & يِش آزمون & \multirow{2}{*}{ محيطى } \\
\hline $1 / 19$ & $\mid r / \Delta \Lambda$ & $1 / r \wedge$ & $1 \pi$ & پֶ آزمون & \\
\hline س & $r \mu / v Q$ & $s / \mu$ & $4 \cdot / 0$ & ييش آزمون & \multirow{2}{*}{ كلى } \\
\hline$\Delta / V G$ & $f \& / .1$ & $r / 90$ & $\Delta r / I V$ & يس آزمون & \\
\hline
\end{tabular}

ميانخين و انحراف استاندارد متغيرهاى موردبررسى در اين فرضيه در جدول Y نشان داده شده است. جهت بررسى فرضيه از آزمون تحليل كوواريانس جندمتغيره استفاده شد. در ابتدا يّشفرضهاى اصلى موردبررسى قرار رفت. نرمالبودن توزيع متغيرها به تفكيك گروههاى آزمايش و كواه بروسى شد.
براى اجراى الكوى رواندرمانى ويثه بيماران قلبى، بيماران

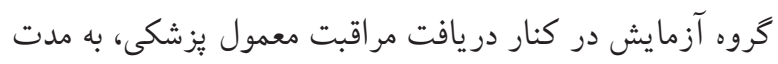

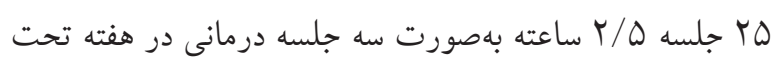

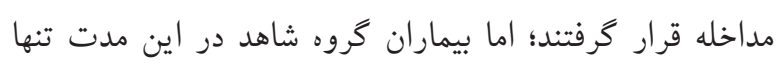

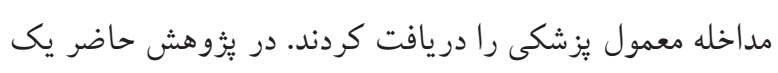

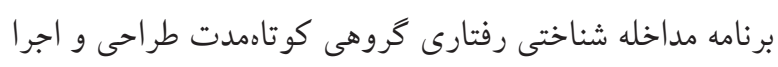

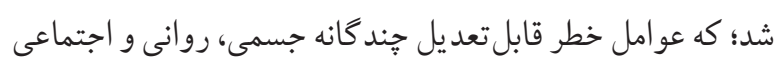

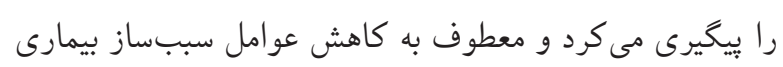

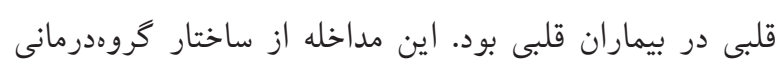

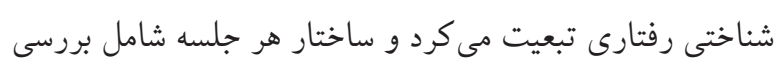

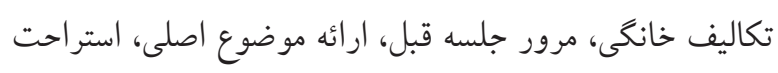

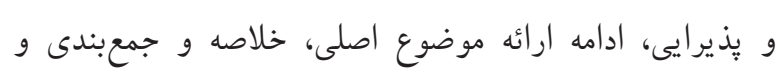

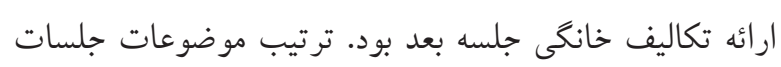

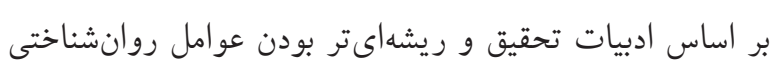
سببساز منظم گرديد.

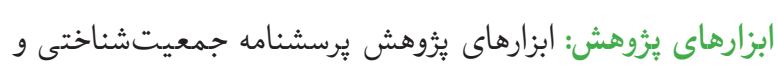

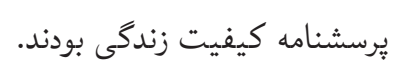

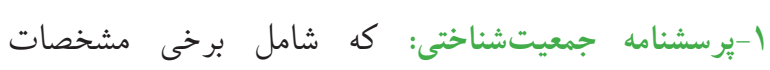

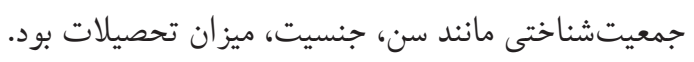

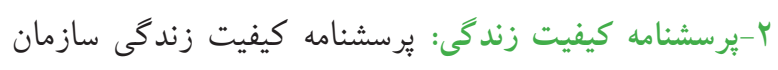

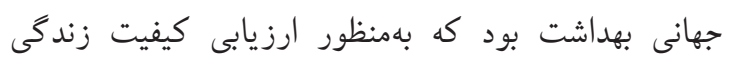

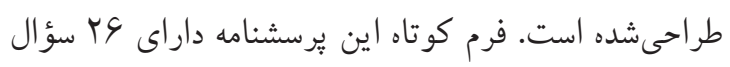

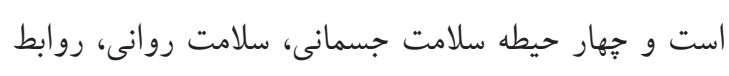

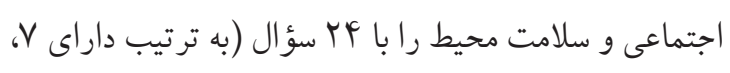

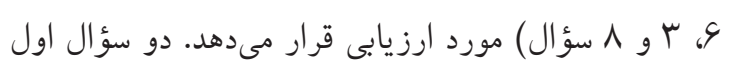

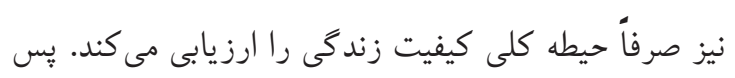

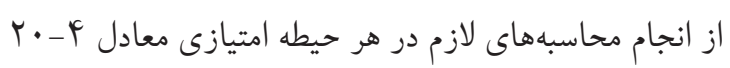

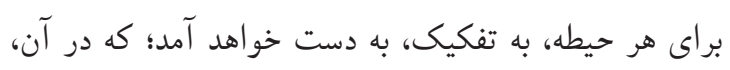

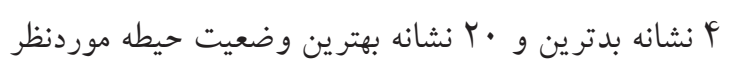

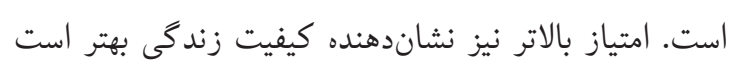

1. cardiovascular specific psychotherapy (CSP) 
معنادار است (ه • / p p). اين معنادارى در بُعد محيطى كيفيت

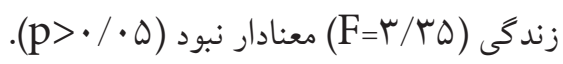

بc

با توجه به نتايج تحليل كوواريانس ارائهشه در جدول أ، درمجموع

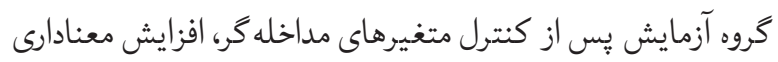
را در نمرات كيفيت زندگى نسبت به گروه كنترل نشان داد. لذا مطالعه حاضر نشاندهنده اثربخشى رواندرمانى ويزه بيماران قلبى بـى بر افزايش كيفيت زندكى بيماران قلبى است. اين يافته با نتايج

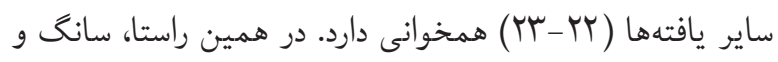

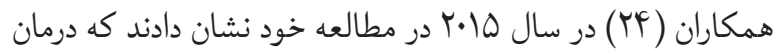
شناختى رفتارى مى تواند سبب كاهش معنادار استرس، اضطراب

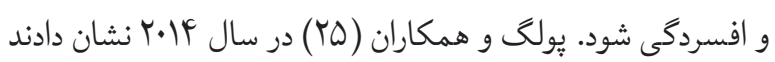

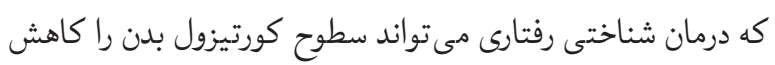

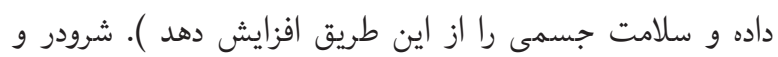

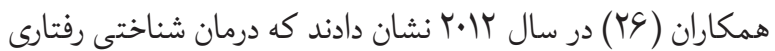

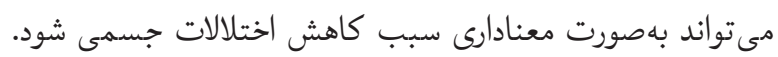

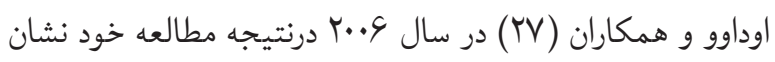

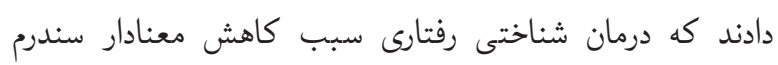

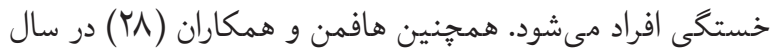

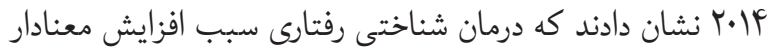

$$
\text { كيفيت زندگى افراد مىشود. }
$$

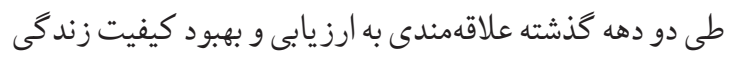

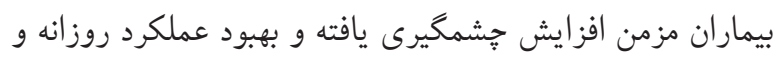
كيفيت زندگى بيماران مبتلا به بيمارىهاى مزمن بهصورت يكى

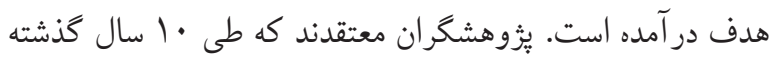

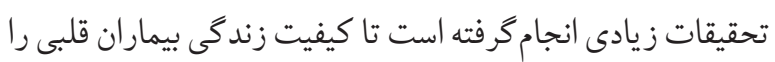

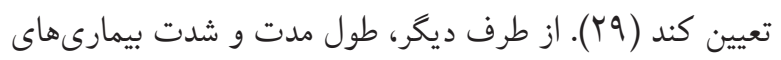
مزمن مانند بيمارىهاى قلبى -عروقى بهاندازهاى است كه كيفيت

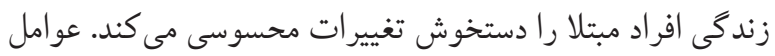
متعددى بر كاهش كيفيت زندگى اين بيماران تأثير گذار است. زير ميرا
آماره كولمو كروف اسميرنوف به تفكيك گروهها معنادار نبودند

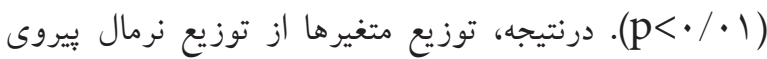

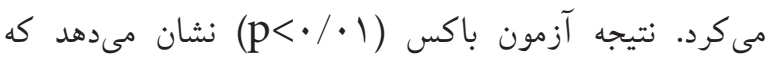
فرض همخنى ماتريسهاى واريانس - كوواريانس برقرار نبود.

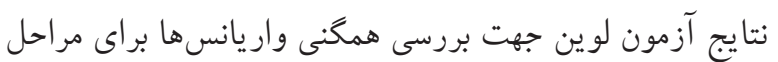

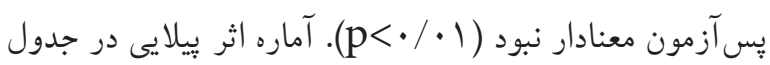

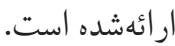
جدول س. آزمونهاى هندمتغيره در تحليل كوواريانس ״ندمتغيره

\begin{tabular}{|c|c|c|c|c|}
\hline اندازه اثر & sig & $\mathbf{F}$ & اثر بيلايى & منبع \\
\hline$\cdot|\vee \&|$ & $\cdot / \cdots 1$ & $1 / r_{q}$ & $\cdot|\vee \&|$ & كروه \\
\hline
\end{tabular}

اطلاعات جدول r نتايج آزمون تحليل كوواريانس جند متغيرى تفاوت گروههاى آزمايش و كنترل را در كيفيت زندكى إنى

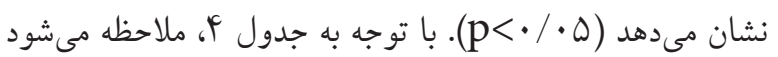

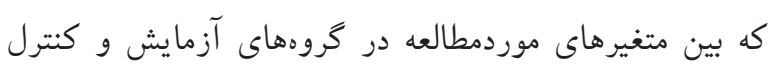
تفاوت معنادارى در سطح هـ/ • • وجود دارد. بر اين اساس، مى توان نتيجه كرفت كه دست كم در يكى از متغيرها بين گروهها، تفاوت معنادارى وجود دارد. براى بى بردن به اين تفاوت، تحليل كوواريانس جندمتغيره در متن مانكوا انجام گرفت كه نتايج حاصل از آنها در جدول أ ارائهشده است. جدول ع. آزمونهاى اثرات يين آزمودنى در تحليل كوواريانس جندمتغيره در كيفيت زندى برنى

\begin{tabular}{|c|c|c|c|c|c|c|}
\hline اندازه اثر & sig & $\mathbf{F}$ & مجذانكين & df & مجذورات & كروه \\
\hline . / TAF & .1 .19 & $s / V^{\mu}$ & $9 / .97$ & 1 & $9 / .9 \mathrm{~V}$ & جسمى \\
\hline ./rGA & r./. & $s / r \mu$ & $1 V / 99$ & 1 & $18 / 99$ & روانى \\
\hline$\cdot / 4 \& s$ &.$/ \cdots 1$ & $\mid F / \wedge \Delta$ & $r q / 40$ & 1 & $r q / 90$ & اجتماعى \\
\hline.$/ 190$ & $\cdot / \cdot \wedge F$ & $\mu / \mu \Delta$ & $r / r \cdot q$ & 1 & $r / r \cdot q$ & محيطى \\
\hline.$/ \mu r$ & $\cdot / \cdot r$ & $I r / A r$ & $r$ rq/Ir & 1 & $r r q / 1 r$ & كلى \\
\hline
\end{tabular}

بر اساس نتايج جدول أل، يّ از تعديل نمرات يِيش آزمون،

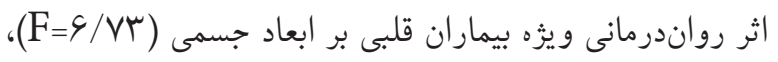

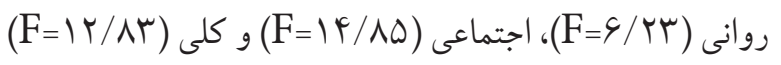


به نظر مىرسد مداخله به كار گرفتهشده در اين يُوهش نيز با استفاده از به كار گيرى موارد مختلف سبب كاهش حس مس نكرانى و اضطراب در رابطه با بيمارى در بيماران قلبى شركت كننده در يُزوهش شده باشد؛ ايم وارد عبارتاند از: استفاده از فنون

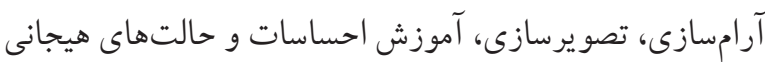

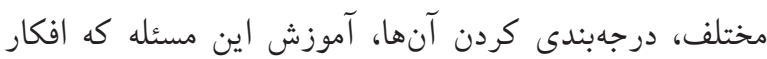

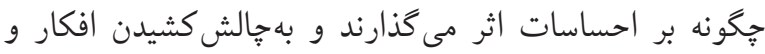

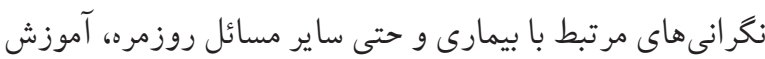
مهارتهاى كنترل خشم، آموزش مهارتهاى مقابلهاى ساز كار. نتايج نشان مىدهد كه درمان شناختى رفتارى باعث افزايش

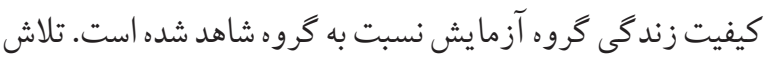

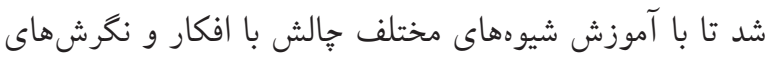

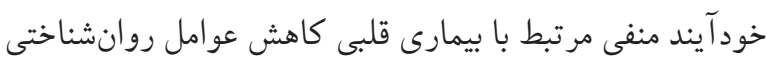
سببساز بيمارى قلبى مورد هدف قراركرفته درنتيجه كيفيت زندكى بيماران بهبود يابد. عملكرد خلقى معيوب، كه شامل علايم

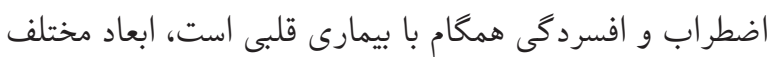

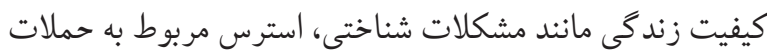

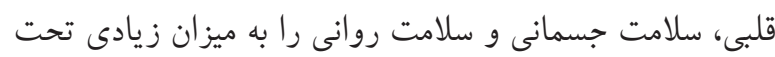

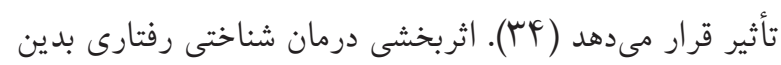
دليل است كه مداخله و تكنيك هاى آموزشى، بهطور مستقيم بر جندين بعد كيفيت زندگى بيماران تأثير كذاشته است (هץ).

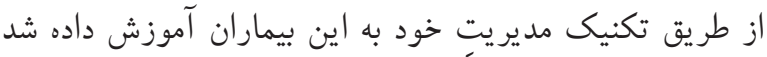

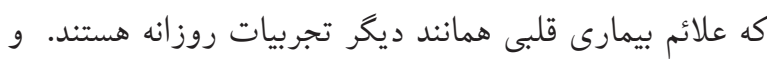

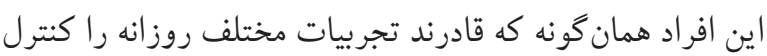
كنند، مىتوانند از طريق شناسايى عوامل برانگيزاننده، علايم و

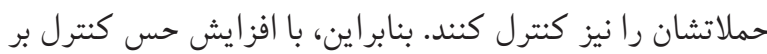
علايم و كاهش بروز نشانها و حملات، كيفيت زندكى بيماران نيز بهبود يِيدا كرد. بيمار ان قلبى دجار تحريفات شناختى و وافكار ناكار آمد متعدد هستند و فعال شدن اين افكار نه تنها باعث تمر كز فرد بروى ظاهر خود، نارزنده سازى و ناميدى نسبت به آينده و درنتيجه كاهش خلق مىشود بلكه موجب افزايش استرس برس
كيفيـت زند گى امرى ذهنى بودهو تحت تأثير عوامل مختلفى نظيـر فرهنگ، محيط فيزيكى، وضعيت اجتمـاعى - اقتصادى، بيمارى،

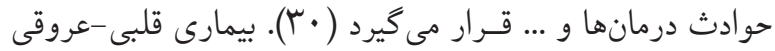
باعث ايجاد محدوديت در فعاليتهاى گروهى، اجتماعى و تفريح،

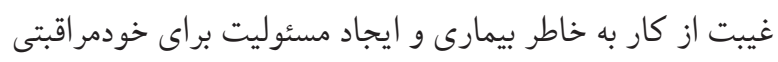
و ييروى از رزيمهاى درمانى بهطور روزانه مىشود. اين اثرات، از طريق كاهش اعتمادبهنفس، كاهش در كيفيت عملكرد اجتماعى، ايجاد نكرانى در رابطه با بروز حمله تنفسى و حتى انزواى اجتماعى،

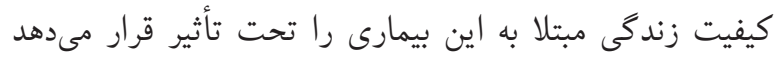

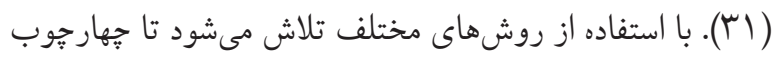
كلى درمان شناختى رفتارى اعمال گردد. اين روشها عبارتانداند

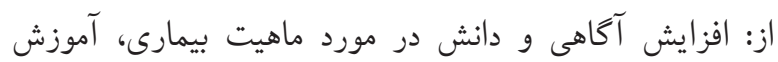
تنفس عميق و ديافراگمى جهت بهتر نفس كشيدن در هنگام

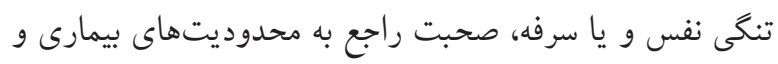

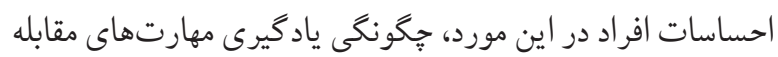

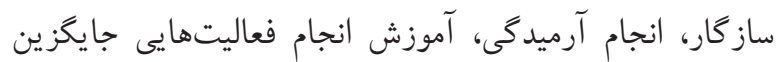

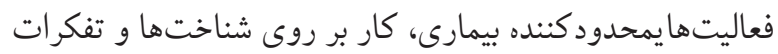

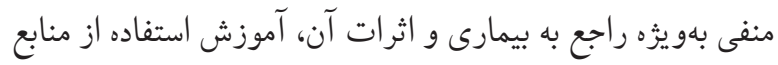

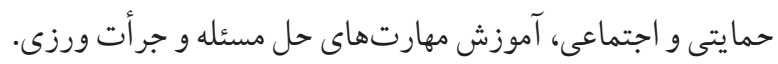
همجنين حضور در جمع همسالانى كه اين محدوديتها را تجربه

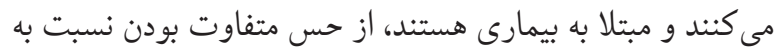
ديكران مى كاهد و باعث مىشود تا افراد از تجربيات يكديكر در مر مبند

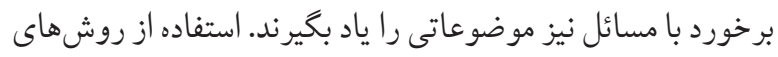

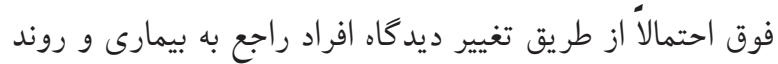

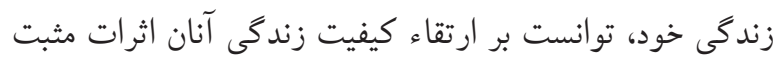

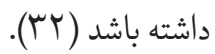

افراد داراى بيمارىهاى مزمن، حساس و مستعد ابتلا به

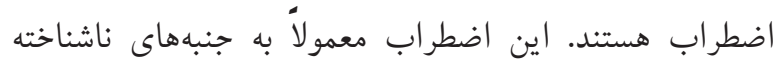
بيمارى، ييشرفت بيمارى، بيش آكهى ضعيف احتمالى، توانايىها

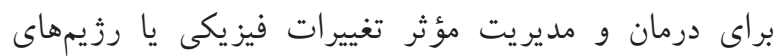
درمانى، توانايى شغلى و عملكرد اجتماعى مربوط است (ساب). 
مورد تأكيد در درمان اصلاح سبك ارتباطى بيماران و افزايش

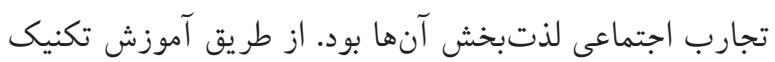

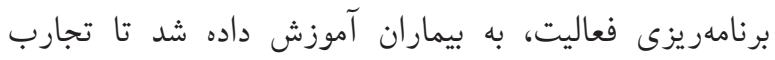
لذتبخش زندگى روزانه و برنامه هفتخى خود را افزايش دهند.

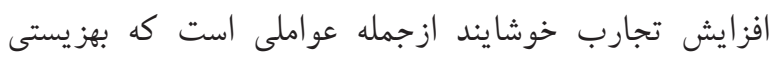
هيجانى بيماران را افز ايش مىدهد. اين يُوهش با بررسى و تائيد اثربخشى رواندرمانى ويثه

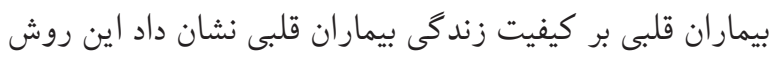

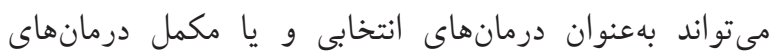
يزشكى در بهبود كيفيت زندكى و بهبود بيماران قلبى به كاربرده

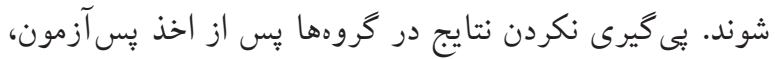
اجراى مداخلههاى درمانى در بازه زمانى كوتاه دوماهه ازجمله

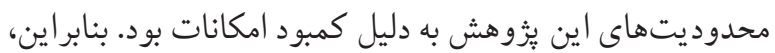

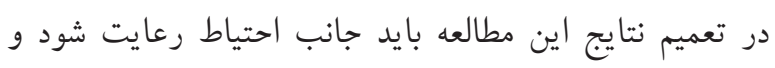

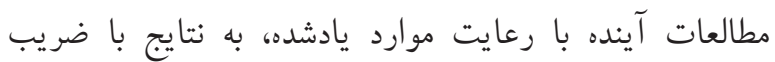

$$
\text { اطمينان بيشترى دست يابند. }
$$

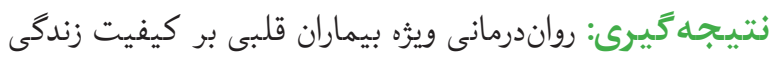

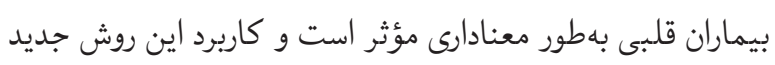

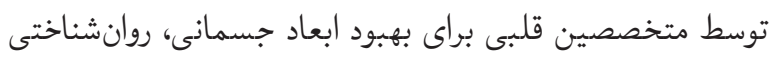
و اجتماعى بيماران قلبى توصيه مىشود. سياسگزן ارى از مسئولين محترم بيمارستان رسول اكرم (ص) رشت و تمامى

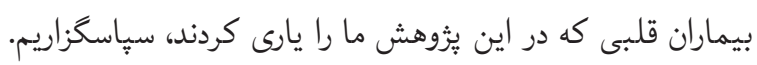

\section{References:}

1. Mazloomy Mahmoodabad SS, Tehrani H, Gholian-aval M, Gholami H, Nematy M. The effect of social class on the amount of salt intake in patients with hypertension. Blood pressure. 2016;25(6):360-3.

2. Sabzmakan LAAJ, Mohammad\%A Nikpajouh, Akbar\%A Bakhtari, Fatemeh. Determinants of Physical Activity among Patients with Cardiovascular Metabolic Risk Factors based on the Educational Factors of PRECEDE Model: A Mixed Method Study. ranian Journal of Health
فرد مى گردد؛ كه خود استرس مىتواند تأثير زيادى بروى علايم بيمارى و جرخه حملات قلبى بحذارد. براى بيماران قلبى فردي

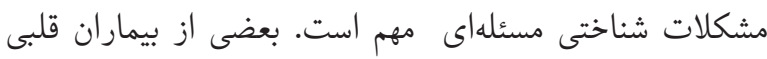

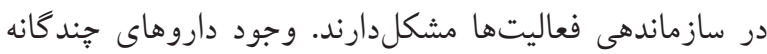

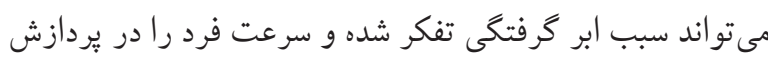
اطلاعات يايين بياورد. اين نقايص ممكن است سبب افزايش وابستكى به ديكران، كاهش احساس ايمنى و از دست دادن اعتماد به فعاليتهاى شخصى خود شود (ب (ب).

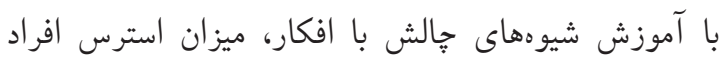

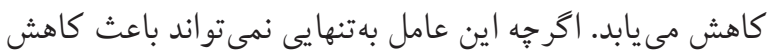
عوامل سببساز بيمارى قلبى شود؛ اما حداقل از بدتر شدن اين

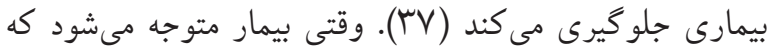
ييشرفت بيمارىاش متوقفشده و يا رو به كاهش است، به

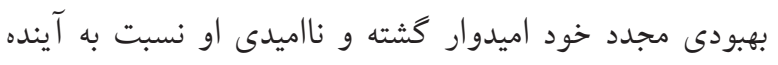
كاهش مى يابد. اين وضعيت خود عامل مؤثرى در بهبود كيفيت زندگى اين بيماران به شمار مىرود. اضطراب و استرس فرد از جهتى خود عامل مؤثرى در تشديد علايم است و از جهت ديكر إنى

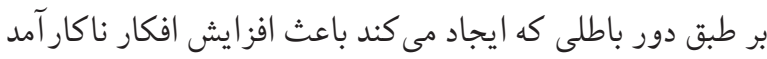

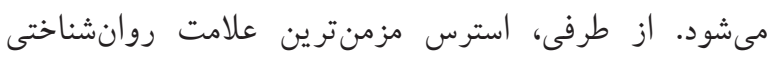
همراه با بيمارى قلبى است. درمان شناختى رفتارى سبب بهبود

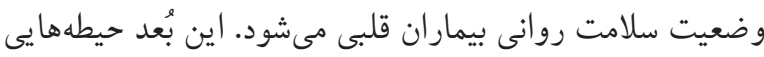

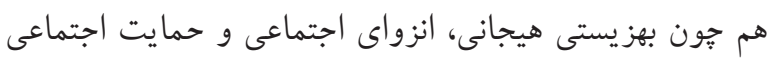

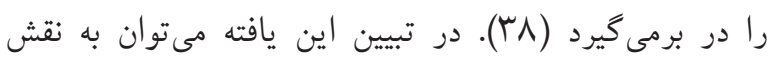

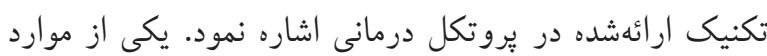

Education and Health Promotion. 2016;4(1):5-19.

3. Schröder A, Rehfeld E, Ornbøl E, Sharpe M, Licht RW, Fink $P$. Cognitive-behavioural group treatment for a range of functional somatic syndromes: randomised trial. $\mathrm{Br} J$ Psychiatry. 2012 Jun;200(6):499-507.

4. Plag J, Gaudlitz K, Schumacher S, Dimeo F, Bobbert $\mathrm{T}$, Kirschbaum $\mathrm{C}$, et al. Effect of combined cognitivebehavioural therapy and endurance training on cortisol and salivary alpha-amylase in panic disorder. J Psychiatr Res. 2014 Nov;58:12-9. 
5. Karimy TAS, Mohsen\%A Sanaeinasab, Hormoz\%A Khalagi, Kazem\%A Hassan-Abadi, Mehdi. Impact of Educational Intervention Based on Theory of Planned Behavior on Lifestyle Change of Patients with Myocardial Infarction. ranian Journal of Health Education and Health Promotion. 2016;3(4):370-80.

6. Conwill M, Oakley L, Evans K, Cavanna AE. CBT-based group therapy intervention for nonepileptic attacks and other functional neurological symptoms: a pilot study. Epilepsy Behav. 2014 May;34:68-72.

7. Agdal ML, Raadal M, Öst L-G, Skaret E. Quality-of-life before and after cognitive behavioral therapy (CBT) in patients with intra-oral injection phobia. Acta Odontol Scand. 2012 Dec;70(6):463-70.

8. van Groenestijn AC, Schröder CD, Visser-Meily JMA, Reenen ETK-V, Veldink JH, van den Berg LH. Cognitive behavioural therapy and quality of life in psychologically distressed patients with amyotrophic lateral sclerosis and their caregivers: Results of a prematurely stopped randomized controlled trial. Amyotroph Lateral Scler Frontotemporal Degener. 2015 Sep;16(5-6):309-15.

9. Agdal ML, Raadal M, Öst L-G, Skaret E. Quality-of-life before and after cognitive behavioral therapy (CBT) in patients with intra-oral injection phobia. Acta Odontol Scand. 2012 Dec;70(6):463-70.

10. Mikocka-Walus A, Bampton $P$, Hetzel D, Hughes $P$, Esterman A, Andrews JM. Cognitive-behavioural therapy has no effect on disease activity but improves quality of life in subgroups of patients with inflammatory bowel disease: a pilot randomised controlled trial. BMC Gastroenterol. 2015;15:54.

11. Hofmann SG, Wu JQ, Boettcher H. Effect of cognitivebehavioral therapy for anxiety disorders on quality of life: a meta-analysis. J Consult Clin Psychol. 2014 Jun;82(3):37591.

12. Agdal ML, Raadal M, Öst L-G, Skaret E. Quality-of-life before and after cognitive behavioral therapy (CBT) in patients with intra-oral injection phobia. Acta Odontol Scand. 2012 Dec;70(6):463-70.

13. Oei TPS, McAlinden NM, Cruwys T. Exploring mechanisms of change: the relationships between cognitions, symptoms, and quality of life over the course of group cognitive-behaviour therapy. J Affect Disord. 2014 Oct;168:72-7.

14. Oei TP, McAlinden NM. Changes in quality of life following group CBT for anxiety and depression in a psychiatric outpatient clinic. Psychiatry Res. 2014 Dec 30;220(3):1012-8.

15. Van Biljon L, Nel P, Roos V. A partial validation of the WHOQOL-OLD in a sample of older people in South Africa. Glob Health Action. 2015;8:28209.

16. Canaway R, Manderson L. Quality of life, perceptions of health and illness, and complementary therapy use among people with type 2 diabetes and cardiovascular disease. J Altern Complement Med. 2013 Nov;19(11):882-90.

17. Ma $Y$, Yang $Y$, Huang $Y$, Zhao $H$, Hou $X$, Tian $Y$, et al. An investigation of symptom burden and quality of life in Chinese chemo-naïve advanced lung cancer patients by using the Instrument-Cloud QOL System. Lung Cancer. 2014 Jun;84(3):301-6.

18. Soo Hoo SY, Gallagher R, Elliott D. Systematic review of health-related quality of life in older people following percutaneous coronary intervention. Nurs Health Sci. 2014 Dec;16(4):415-27.

19. Braga Filho RT, D’Oliveira Júnior A. Metabolic syndrome and military policemen's quality of life: an interdisciplinary comprehensive approach. Am J Mens Health. 2014 Nov;8(6):503-9.

20. Van Biljon L, Nel P, Roos V. A partial validation of the WHOQOL-OLD in a sample of older people in South Africa. Glob Health Action. 2015;8:28209.

21. Shal RS, Sharbaf HA. Survey the Prevalence of Psychopathology in Coronary Heart Disease Patients: A Casual Model Based on Analysis of the Role of Psychological Factors. Jundishapur Journal of Chronic Disease Care [Internet]. 2013;2(4).

22. Hesselmark E, Plenty S, Bejerot S. Group cognitive behavioural therapy and group recreational activity for adults with autism spectrum disorders: a preliminary randomized controlled trial. Autism. 2014 Aug;18(6):67283.

23. Kavitha C, Rangan U, Nirmalan PK. Quality of life and marital adjustment after cognitive behavioural therapy and behavioural marital therapy in couples with anxiety disorders. J Clin Diagn Res. 2014 Aug;8(8):WC01-4.

24. Tsang HWH, Cheung WM, Chan AHL, Fung KMT, Leung AY, Au DWH. A pilot evaluation on a stress management programme using a combined approach of cognitive behavioural therapy (CBT) and complementary and alternative medicine (CAM) for elementary school teachers. Stress Health. 2015 Feb;31(1):35-43.

25. Plag J, Gaudlitz K, Schumacher S, Dimeo F, Bobbert $T$, Kirschbaum $C$, et al. Effect of combined cognitivebehavioural therapy and endurance training on cortisol and salivary alpha-amylase in panic disorder. J Psychiatr Res. 2014 Nov;58:12-9.

26. Schröder A, Rehfeld E, Ornb $\emptyset \mid E$, Sharpe M, Licht RW, Fink P. Cognitive-behavioural group treatment for a range of functional somatic syndromes: randomised trial. $\mathrm{Br} \mathrm{J}$ Psychiatry. 2012 Jun;200(6):499-507.

27. O'Dowd H, Gladwell P, Rogers CA, Hollinghurst S, Gregory A. Cognitive behavioural therapy in chronic fatigue syndrome: a randomised controlled trial of an outpatient group programme. Health Technol Assess. 2006 
Oct;10(37):iii - iv, ix - x, 1-121.

28. Hofmann SG, Wu JQ, Boettcher H. Effect of cognitivebehavioral therapy for anxiety disorders on quality of life: a meta-analysis. J Consult Clin Psychol. 2014; 82(3):375-91.

29. Mikocka-Walus A, Bampton P, Hetzel D, Hughes P, Esterman A, Andrews JM. Cognitive-behavioural therapy has no effect on disease activity but improves quality of life in subgroups of patients with inflammatory bowel disease: a pilot randomised controlled trial. BMC Gastroenterol. 2015; 15:54.

30. Agdal ML, Raadal M, Öst L-G, Skaret E. Quality-of-life before and after cognitive behavioral therapy (CBT) in patients with intra-oral injection phobia. Acta Odontol Scand. 2012; 70(6):463-70.

31. van Groenestijn AC, Schröder CD, Visser-Meily JMA, Reenen ETK-V, Veldink JH, van den Berg LH. Cognitive behavioural therapy and quality of life in psychologically distressed patients with amyotrophic lateral sclerosis and their caregivers: Results of a prematurely stopped randomized controlled trial. Amyotroph Lateral Scler Frontotemporal Degener. 2015; 16(5-6):309-15.

32. Agdal ML, Raadal M, Öst L-G, Skaret E. Quality-of-life before and after cognitive behavioral therapy (CBT) in patients with intra-oral injection phobia. Acta Odontol
Scand. 2012; 70(6):463-70.

33. Conwill M, Oakley L, Evans K, Cavanna AE. CBT-based group therapy intervention for nonepileptic attacks and other functional neurological symptoms: a pilot study. Epilepsy Behav. 2014; 34:68-72.

34. Shimodera S, Watanabe N, Furukawa TA, Katsuki F, Fujita $H$, Sasaki $M$, et al. Change in quality of life after brief behavioral therapy for insomnia in concurrent depression: analysis of the effects of a randomized controlled trial. J Clin Sleep Med. 2014 15; 10(4):433-9.

35. Graham CD, Simmons Z, Stuart SR, Rose MR. The potential of psychological interventions to improve quality of life and mood in muscle disorders. Muscle Nerve. 2015; 52(1):131-6.

36. Chien H-C, Chung Y-C, Yeh M-L, Lee J-F. Breathing exercise combined with cognitive behavioural intervention improves sleep quality and heart rate variability in major depression. J Clin Nurs. 2015 Nov;24(21-22):3206-14.

37. Wise J. Cognitive behavioural therapy shows promise in heart failure patients with depression. BMJ. 2015;351:h5163.

38. Mayou RA, Bryant BM, Sanders D, Bass C, Klimes I, Forfar C. A controlled trial of cognitive behavioural therapy for noncardiac chest pain. Psychol Med. 1997 Sep;27(5):1021-31. 